\title{
Modern financial and legal relations trends and economy digitalization
}

\author{
Igor Semukhin ${ }^{1}$, Svetlana Kolovaylo ${ }^{2 *}$ and Natalia Kravchenko ${ }^{3}$ \\ ${ }^{1}$ Crimean branch of the Federal State Budget-Funded Educational Institution of Higher Education "The Russian State University \\ of Justice", Simferopol, Russia, semmich@mail.ru \\ ${ }^{2}$ Crimean branch of the Federal State Budget-Funded Educational Institution of Higher Education "The Russian State \\ University of Justice", Simferopol, Russia, bolero_8@mail.ru \\ ${ }^{3}$ Crimean branch of the Federal State Budget-Funded Educational Institution of Higher Education "The Russian State University \\ of Justice”, Simferopol, Russia, nataliakravchenko85@gmail.com
}

\begin{abstract}
The article considers the trends in the development of financial and legal relations, which are caused by changes taking place in economic and social relations through the introduction of digital technologies. In conducting the study the authors analyzed the totality of currency, banking relationships, insurance relationships, budgetary legal relations and financial market relations. As a result of the study, the authors concluded that it is necessary to improve the mechanism of legal regulation of the use of such financial instruments as blockchain, cryptocurrency, etc., as well as the supervisory functions of the Bank of Russia credit bureaus in order to increase confidence in financial market participants.The authors also justify the need to introduce specific taxes (taxation on payments made for the purchase of goods and services over the Internet, or a tax on turnover from commercial activities on the world wide web) in order to prevent digital businesses from tax avoidance. An implication of the analyses is identifying tools that ensure a transparency of the budget system. Control approaches themselves have also been transformed. Thus, risk-based approaches have been used, as well as ratings of control objects by the level of reliability. It also requires further analysis of the regulatory tools that can be applied by public authorities, changes in the object and tax base, the procedure for collecting taxes, and possible tax benefits. The results can be used in further research to develop an effective legal mechanism for regulating financial and legal relations in modern economic condition.
\end{abstract}

\section{Introduction}

The current stage of the development of public relations is characterized by the active introduction of digital technologies. It should be noted that the distribution of coronavirus infection COVID-19 caused by SARS-CoV2 in 2020 , determined a more rapid transformation of relations, manifested in the rising of remote activities, increasing the volume of electronic sales of goods and services including government services to accelerate the digital transformation of enterprises. Thus, since 2008, the number of Internet users has grown 2.5 times and reached 4.1 billion in 2020, the number of Internet users and people who use online shopping services has doubled, the volume of retail trade on the Internet has almost quadrupled (3.8 trillion US dollars), experts predict an increase in the provision of financial services through financial services twice [1-2]. These transformations, which are specific to the current stage of development of public relations, have predetermined changes in the composition and structure of financial and legal relations, which necessitates the analysis of the content of these legal relations in order to develop a legal mechanism for their regulation in the future.

\section{Problem Statement}

It should be noted that the process of introducing digital technologies in all spheres of public life, along with improving the quality and availability of services, increasing the productivity and competitiveness of enterprises, reducing production costs, determines the emergence of such risks as unauthorized access to information, mass unemployment, digital inequality, etc. Thus, according to the Ministry of internal Affairs of the

\footnotetext{
* Corresponding author: bolero_8@mail.ru
} 
Russian Federation, in 2019, the number of crimes committed using information technologies increased by $60-70 \%$ compared to the previous period [4]. In accordance with the passport of the Federal project Regulatory regulation of the digital environment, it is planned to change the current legislation, including those related to the financial activities of the state [4]. Thus, a necessary condition for the introduction of digital technologies is to determine the legal status and procedure for the turnover of digital financial assets, establish conditions for VAT taxation, export operations of works and services, regulate the taxation of participants in crowdfunding platforms, and ensure the legal settlement of legal relations related to the development of the digital economy and the activities of investment platforms.

\section{Research Questions}

In order to offset the negative consequences of the introduction of information technologies, it is necessary to analyze trends in financial and legal relations caused by the introduction of digital technologies, such as:

3.1 Analysis of trends in the development of insurance, banking, currency relations in the field of financial legislation.

3.2 Analysis of trends in the development of tax and budget legal relations in the field of state loans.

\section{Purpose of the Study}

Taking into account the transformations inherent in the modern stage of development of public relations, which are manifested in the active introduction of information technologies, it is relevant to analyze the changes in financial and legal relations during the transition to the digital economy.

\section{Research Methods}

The goal was achieved through the use of general scientific methods, such as the analysis of literature and legal documents on the subject of research, the study and generalization of information, abstraction, induction and deduction. The method of analogy and modeling was used. When studying the legislation, a comparative legal method was used.

\section{Findings}

Defining the essence of financial legal relations, it should be noted that in all doctrinal approaches to determining the content of the term presented in the scientific literature, the authors are United in indicating the scope of these legal relations. Taking into account the variety of financial legal relations, various approaches to their content and classification have been formed in the scientific literature. So, generalizing approaches to classification depending on the sphere of financial activity or the content of the financial and legal norm, it is possible to present such types of financial relations as budget, tax, insurance, state credit, currency, banking, financial market regulation, financial control [5-6]. According to the authors this approach to the classification of financial legal relations gives the most complete picture of the totality of legal relations that are the subject of financial law.

In order to conduct this research, it is also necessary to define the content of the term "digitalization of the economy". As a result of the analysis of scientific approaches, the authors came to the conclusion that this category characterizes the process of changing social relations through the introduction of information and telecommunications technologies that improve the efficiency of economic activity. It should be noted that the most significant changes have been made in currency and banking legal relations, as well as in the field of financial market regulation, which is due to the emergence of a completely new type of relations related to the use of electronic money (cryptocurrency). According to scientists, the global financial crisis of 2008 is a prerequisite for the active introduction of digital technologies in banking legal relations. Thus, the failure of the banking system and the low turnover rate of financial assets caused the stagnation of the entire world economy. These trends predetermined the introduction of digital network technologies and tools, which led to a significant increase in competition in the financial sector, including through financial and technological innovation, as well as the formation of a parallel interactive virtual space that no longer obeyed traditional laws and management methods. The main advantage of new financial technologies should be considered the possibility of cloud data storage, which fully corresponds to the rapidly changing context of financial transactions from mobile devices, at any time of the day and from anywhere in the world. The legislation of the Russian Federation are not clearly regimented and only indirectly defines the concept of cloud technology in the "strategy of information society development in Russian Federation to 2017 - 2030" as “... an automated way to provision computing power, including software in remote access mode via the Internet at the client's request or... the technological model, which is any physical resource from the virtual model." [7].

However, Russian legislation cannot yet provide an adequate response to the challenges of modern times in terms of legal regulation of rapidly developing financial instruments on the digital market. This is due to the specifics of financial regulatory technologies, their high integration into digital categories, such as cryptocurrency, blockchain, and others, as well as the lack of a rule of law regulating the circulation of the above-mentioned financial instruments. The lawmaker is late, and the digital financial market is developing too fast. In this context, it is fair to conduct a legal assessment of the Federal law of 31.07.2020 N 259-FZ "on digital financial assets, digital currency and on amendments to certain legislative acts of the Russian Federation " [8], which will enter into force on January 01, 2021. 
Thus, at the legislative level, the concept of "digital financial assets" (hereinafter referred to as DFA) is defined, which are digital rights secured by monetary claims. Accounting and handling of the DFA are carried out only by changing the information code, in other words, changing the distributed registry. At the same time, DFA will be recorded in the system in which they are issued, and they will be modified at the issuer's direction, which will allow the Bank of Russia to determine DFA that can only be purchased by qualified investors, classifying them according to certain digital characteristics. Transactions with the DFA will be concluded through a specialized exchange operator.

The above-mentioned regulatory legal act defines the content of the term "cryptocurrency", which will now be replaced by the term "digital currency", as a digital code, a set of data that is not a monetary unit, but which can be accepted as an investment or payment, considered as property in the new versions of the law on bankruptcy and enforcement proceedings. It should be noted that, despite the legal regulation of the use of digital currencies, the law prohibits not only accepting payment for goods and services in digital currency, but also spreading information that digital currency can be used as a method of payment for goods or services.

The transformation of banking legal relations in the context of digitalization of the economy is manifested in the use of RegTech tools that are used for customer identification, detection of suspicious activity and fraud prevention, reporting, and compliance control. The use of these tools makes it possible to increase the effectiveness of financial control over the activities of financial market participants by automating part of administrative procedures, digitalizing the interaction of participants, and improving the quality of reporting information.

Financial and legal relations in the insurance sector have also been transformed. Thus, according to experts, the main trend of development of insurance market in 2019 was to automate their provision [9], allowing, on the one hand, more quickly and to provide quality insurance services to settle insurance claims, and identified the need to develop and study tools to monitor the organization of the insurance business. For example, the changes made to the Federal law "On the organization of insurance business in the Russian Federation" on April 24, 2020, made it possible to exchange information within the legal framework through technical means, mobile devices, tablets, etc., and the individual policyholder also has the opportunity to provide information to the insurer through a financial platform, the operation of which is planned from January 2021, which will "promote competition in the financial market, increase convenience, transparency and efficiency of receiving services by clients in the "single window" mode, elimination of barriers to access to clients' financial products" [10].

According to the amendments the operator of the financial platform is neither a broker nor a dealer, which eliminates the ambiguity in the regulatory settlement of these legal relations and duplication of requirements imposed by the Central Bank of the Russian Federation for the implementation of its activities. The emergence of a new subject of insurance legal relations - the operator of the financial platform, determines the need to determine its place in financial legal relations, as well as their content. This entity, together with the implementation of financial services activities, will perform financial monitoring functions. It should be noted that in order to ensure the effective functioning of financial service operators, it is necessary to change the current legislation, in terms of the adoption of special laws on the registrar of financial transactions, on the financial aggregator, as well as legislation on products and the responsibility of bot developers.

These transformations of banking and insurance legal relations, as well as the regulation of the securities market, allow us to conclude that the functions performed by the Central Bank of the Russian Federation as a subject of financial legal relations are significantly transformed. Thus, it is responsible for solving such tasks as improving the Supervisory powers of the Bank of Russia and credit bureaus in order to increase confidence in financial market participants.

Tax relations have also been transformed. The modern system of taxation is based on principles that were laid down in the works of A. Smith and have not changed much over the centuries, such as fairness, convenience, efficiency or economy. These principles remain relevant, and such principles as benefits and solvency are the Foundation of the tax system of every country in the world. At the same time, trends in the development of this system of public legal relations are characterized by changes in the priorities of socioeconomic development, sources of income, transformation of the tax systems, organization of tax collection, by shifting the focus from one object of taxation to another, expanding tax bases or reducing benefits. These transformations are due to the impact of technological progress and globalization. Taking into account these changes, it is necessary to determine the legal consequences for the modern tax system, analyze the regulatory tools that can be applied by public authorities, change the object and base, the procedure for collecting taxes, and tax benefits.

It should be noted that in a short time, digital assets have become an integral part of the life of modern enterprises. The digital transformation of industrial enterprises is uneven - some companies are already using digital technologies at all stages of the product lifecycle (from development to maintenance), while others are only studying the benefits and costs of such implementation. However, almost all businesses use Internet space to sell their products and services [11]. According to the research of $\mathrm{PwC}$, the development trends of business entities in the next five years will be to reduce costs by $3.6 \%$ and increased income by $2.9 \%$ due to the digitization of products and services and develop new offerings digital services [12]. These transformations will contribute to the growth of tax revenues due to revenue growth.

However, it should be noted the risks of reducing budget revenues by reducing the tax base, due to the widespread use of digital goods and services. These 
trends are due to the fact that digital goods reduce the tax base due to the lower cost of digitized goods such as, for example, audiobooks. Another factor that determines the reduction of the tax base may be the complexity of determining the subject of taxation, since there are socalled income without citizenship.

The impact of digitalization on the tax system, as well as methods for solving problems in the context of the transformation of socio-economic relations is presented in table 1 .

Table 1. Cross-analysis of the impact of digitalization on the tax system

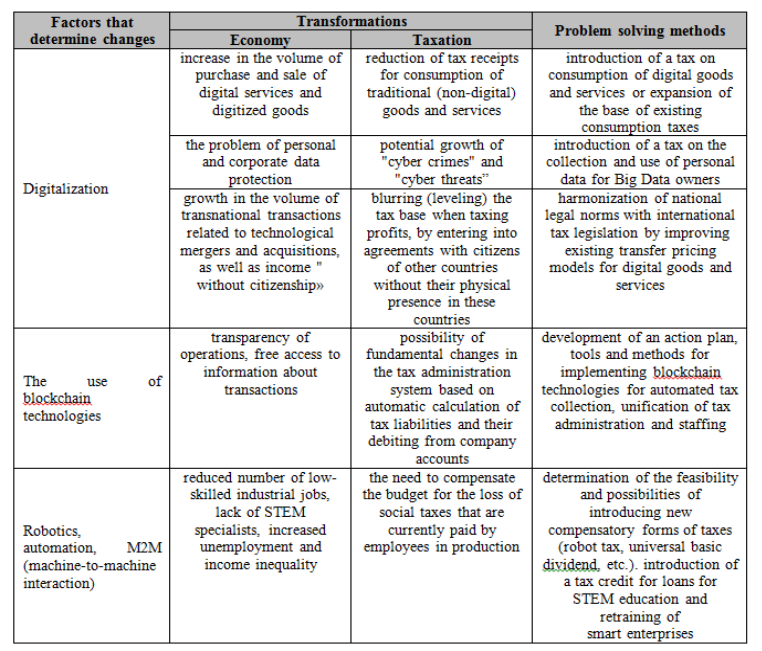

These changes in socio-economic development caused by the introduction of information technologies have determined the need to adapt international tax systems. After judicial investigations into tax evasion by digital giants such as Amazon and Google and finding them innocent, the European Union has begun work to protect national tax systems and minimize the risks of non-payment of tax obligations by digital companies and platforms. One of the proposals is to introduce specific taxes (a tax on payments made for the purchase of goods and services over the Internet, or a tax on turnover from commercial activities on the world wide web) in order to prevent digital businesses from avoiding responsibility [13].

At the moment, international practice is characterized by the introduction of additional provisions in the tax codes on taxation of foreign supplies of digital services and goods. An example of taxation of imported / exported digital goods and services is the indirect tax of $10 \%$ introduced in Australia from 2019. Tax rates for digital goods and services vary from country to country. So, in New Zealand, the corresponding tax rate is $15 \%$, in Japan-8\% [14]. In the European Union, the supplier of electronic goods and services pays VAT in the buyer's country. The Russian Federation has introduced the socalled Google tax, which is essentially a value-added tax on digitized goods and electronic services sold via the Internet by foreign it companies [15].

Unauthorized use of information is another negative consequence of the digitalization of public relations, which can be leveled through, among other things, tax instruments. According to a study by the analytical company "Javelin Strategy", in 2019, the largest number of cases of online fraud were registered, resulting in $\$ 16$ billion in damage [16]. In addition, digitalization, the use of digital platforms and blockchain, leads to the formation of data arrays, known as Big Data, where large amounts of personal and corporate information are accumulated. The latter is collected and used by large and small electronic systems that form catalogs of habits, tastes, recent user requests, personal data, Bank details, and so on (Poritskiy, Oliveira \& Almeida, 2019).

It should be noted that one of the directions of legal regulation of digitalization processes in the Russian Federation could be the adoption of the law "on digital/electronic economy". The adoption of this normative legal act would consolidate the conceptual framework and to determine basic categories such as digital economy, electronic business, electronic Commerce, electronic contract, electronic services, eGovernment, competent authorities, electronic communications, online store, consumers of e-services, etc., and also subject composition relations, their rights and obligations in the field of digital economy, mechanisms for the protection of their rights and legitimate interests, the liability for violations in this sphere and consequences of abuse of rights, features of conflict resolution.

The adoption of this normative legal act would correspond not only to the basics of the development of the information society in Russia (to improve the information legislation in terms of its codification), but also would give participants of digital economy, which is developing very rapidly and replacing traditional forms of business, more opportunities to exercise their rights and interests and at the same time protect them in case of violation.

The introduction of digital technologies in the budget sphere ensures the transparency in the formation, distribution and use of public funds by providing citizens with an opportunity to evaluate the activities of budget resources management and exercise public control. One of the tools to ensure transparency of the budget system is the state integrated information system for public Finance management "Electronic budget". Control approaches themselves have also been transformed. Thus, risk-based approaches, as well as ratings of objects of control by the level of reliability, were used when determining the plan of control measures implemented by the Federal Treasury. When regulating budget legal relations, it should be noted that it is necessary to make changes to the current legislation in terms of introducing special rules that would regulate the information support of the budget process.

\section{Conclusion}

Thus, as a result of the research, the authors came to the conclusion about a significant change in public relations, which is the subject of financial law, under the influence of the rapid introduction of digital technologies.

So, it requires improvement of the legal mechanism of regulation of financial instruments such as 
cryptocurrency, blockchain etc. Changes in insurance and banking legal relations, as well as financial market regulation, determine the need to improve the Supervisory powers of the Bank of Russia and credit bureaus in order to increase confidence in participants in the financial services market and ensure the stability of its functioning.

It should be noted that there is a characteristic change in the priorities of socio-economic development, sources of income, transformation of the tax systems, organization of tax collection, by shifting the focus from one object of taxation to another, expanding tax bases or reducing benefits. Taking into account these changes, it is necessary to further analyze the legal consequences for the modern tax system, regulatory instruments that can be applied by public authorities, changes in the object and base, the procedure for collecting taxes, and tax benefits. Another characteristic feature is the introduction of specific taxes (a tax on payments made for the purchase of goods and services over the Internet, or a tax on turnover from commercial activities on the world wide web) in order to prevent digital businesses from avoiding responsibility.

Also, as a result of the analysis, the authors justify the need to adopt the law "on digital / electronic economy", which would consolidate the conceptual apparatus and define such basic categories as the digital economy, electronic business, electronic Commerce, electronic contract, electronic services, electronic government, electronic authorized bodies, electronic information exchange, online store, consumers of electronic services, etc., as well as the subject structure of relations, their rights and obligations in the digital economy, mechanisms for protecting their rights and legitimate interests, responsibility for violations in this area and the consequences of abuse of rights, features of conflict resolution.

Digitalization of budget legal relations is manifested in the use of tools that allow ensuring transparency of the budget system, such as the state integrated information system for public Finance management "Electronic budget". Control approaches themselves have also been transformed. Thus, risk-based approaches, as well as ratings of objects of control by the level of reliability, were used in determining the plan of control measures implemented by the Federal Treasury. When regulating budget legal relations, it should be noted that it is necessary to make changes to the current legislation in terms of introducing special rules that would regulate the information support of the budget process.

\section{References}

1 Accounts Chamber of the Russian Federation. Digital technologies and cybersecurity in the context of the spread of COVID-19 (2020), URL: https://ach.gov.ru/upload/pdf/Covid-19-digital.pdf (date of access:14.04.21)

2 Central Bank of the Russian Federation. The main directions of development of financial technologies for the period 2018-2020 (2018) URL:
//cbr.ru/Content/Document/File/84852/ON_FinTex_ 2017.pdf (date of access: 14.04.21)

3 Ministry of internal Affairs of Russia. Brief description of the state of crime in the Russian Federation for January-December 2019 (2019), URL: https://мвд.pф/reports/item/19412450/ (date of access: 14.04.21)

4 Government Commission on digital development and the use of information technologies to improve the quality of life and business environment. Passport of the Federal project "Regulatory regulation of the digital environment", 9. (2019), URL: //legalacts.ru/doc/pasport-federalnogoproekta-normativnoe-regulirovanie-tsifrovoi-sredyutv-prezidiumom/(date of access:14.04.21)

5 A.A. Musatkina, \& E.V. Chuklova, Financial Law: Textbook. (Moscow, Russia: INFRA-M, 2015)

6 A.I. Zemlin, O.M. Zemlina, \& N.P. Olkhovskaya Finasncial law of the Russian Federation: textbook for universities (Moscow, Russia / Yurayt Publishing House, 2020)

7 President of the Russian Federation. Decree of 5.9.2017 N 203 "On the Strategy for Information Society Development in the Russian Federation for 2017 - 2030" (May 15, 2017 N 20, item 2901) (Moscow, Russia: Collected Legislation of the Russian Federation, 2017)

8 Government of the Russian Federation. Federal Law of July 31, 2020 N 259-FZ "On digital financial assets, digital currency and on amendments to certain legislative acts of the Russian Federation" (August 03, 2020 No. 31). Moscow, Russia: Collected Legislation of the Russian Federation, 2020)

9 State Duma of The Russian Federation. The main trends in the development of the digital economy in the financial sector. Legal aspects of regulation and practical application. (Moscow, Russia: State Duma Publication, 2019)

10 Government of the Russian Federation. Federal Law of July 31, 2020 N 259-FZ "On digital financial assets, digital currency and on amendments to certain legislative acts of the Russian Federation" (August 03, 2020 No. 31). (Moscow, Russia: Collected Legislation of the Russian Federation, 2020).

11 J. Luoma-Kyyny, Data sovereignty and soft infrastructures are key enablers for the next phase of the European data economy (2020), URL: //www.sitra.fi/en/news/data-sovereignty-and-softinfrastructures-are-key-enablers-for-the-next-phaseof-the-european-data-economy/ (date of access:14.04.21)

12 The future of financial services. PricewaterhouseCoopers (2020) URL: //www.pwc.com/gx/en/industries/financialservices/publications/future-of-financialservices.html (date of access: 14.04.21)

13 After Amazon, EU considers next steps on new digital taxes. (2017) URL: //tech.eu/features/17463/amazon-eu-new-digital-taxlaws (date of access: 14.04.21) 
14 Taxes on Survey Monkey Purchases. (2017). Retrieved from https://help.surveymonkey.com/articles/ru/kb/Taxes /

15 Trakman, L., Walters, R., \& Zeller, B. (2019). Tort and data protection law: Are there any lessons to be learnt? European Data Protection Law Review, 5(4), 500-519.

16 Buzzard, J. (2020). Identity Fraud in the Digital Age Retrieved from https:/www.javelinstrategy.com/coveragearea/identity-fraud-digital-age 